\title{
COMING TOGETHER: GEOGRAPHY AND CITIZENSHIP EDUCATION FOR SUSTAINABLE LIVING
}

Prof. Karmen Kolnik, PhD

Oddelek za geografijo, Filozofska fakulteta, Univerza v Mariboru, Slovenija e-mail: karmen.kolnik@uni-mb.si

\begin{abstract}
The new directions in geography education are predicated not only on the need for knowledge, but also on critically stimulating its development. They view knowledge as a positional good that contributes to the personal social activity of the individual and enables the realization of his privileges, rights and social responsibility.

In order to implement these innovations in geographical education and education for sustainable development, stimuli for anticipatory learning and democratic participatory learning-based on interdisciplinary connections and a holistic approach-must be consolidated in a conjunction of necessary educational content for the purpose of creating an active citizenship.

The article presents some viewpoints we have to consider in educating and upbringing sustainable and literate citizens which are locally, regionally and globally aware. For reaching that a cross-curricular education should involve a wide range of multidimensional learning goals and we find some important ones.

Understanding and realizing the principles of balanced sustainable development should not be a topic for working documents alone. These must become component parts of the knowledge and educational values integral to the educational process.
\end{abstract}

Key words: geography, sustainable development, citizenship, interdisciplinary learning

\section{Introduction}

Adequate circumstances, conditions and environment for forming responsible citizens are created by different factors, amongst which the educational system is highly important. It is crucial that teachers of different school subjects are aware that they can and must co-create their pupils' civic role as a role for life.

"Geography is about places. It is not just about knowing about places themselves, but understanding the interdependence and connectivity of places. It is 
about empowering tomorrow's adults to develop real global understanding and global citizenship so that they have the intellectual understanding to participate individually and collectively in shaping the world around them". (Bell 2005, p13) Geography involves active discovery of the world and thinking about how we relate to it in order to better comprehend, explain and predict how human and physical interactions affect and are affected by day-to-day decisions. Consequently, questions of the "what can I do?" and "why, where and how?" variety demanded by citizenship are already familiar to geographers, who possess the skills to respond. For this reason alone, geography has a built-in "citizenship dimension." Citizenship also demands self-awareness and the impetus to engage with the surrounding world, and geography is uniquely placed to assist us in gaining a sense of who we are in the world and how we interact with others. (1 http://www, 2008)

In the future it is expected that space - its location and organization and human-environment interaction will continue to be the foundation of geographical education, because together with the encouragement of spatial learning, they encourage the development of participatory and proactive learning as important elements in an educational progress geared for permanent and ongoing development. Geography education can contribute significantly to learning about (knowledge), understanding and respecting (evaluation) one's homeland and national space and their co-dependent connection with the world. Geography education can substantially contribute to the learning of values, behaviour and lifestyles required for a sustainable future. By bringing global problems of the world up to date, we can educate pupils in awareness of their own rights and also of their responsibility for the future. All pupils (citizens) deserve the chance to develop skills for social and political participation on different levels of decision-making and to become enthusiastic about common problem solving, solidarity, and the quest for balance between individuality and community, between man and nature.

In 1998, the UK government report on education for citizenship (QCA), at the Crick Report, set out three interrelated strands in Citizenship education (Powell \& Basini, 2006):

- Social and moral responsibility; Pupils developing self-confidence along with morally and socially responsible behaviour both in and outside the classroom, towards those in authority and towards each other;

- Community involvement. Pupils learning how to become involved in the life and concerning of their neighbourhood and community;

- Political literacy. Pupils learning about the institutions, issues, problems and practices of our democracy.

Huckle (2005) suggests that school subjects themselves should take a postmodern didactic turn if they are to be more effective agents of education for sustainable development. This will involve a deflection from the methods of empiricism and positivism in the direction of more empowering philosophical frameworks that allow subjects greater opportunities to foster sustainability as a mindset as they explore the interaction between the bio-physical and social worlds. Up-to-date ideas from social and cultural theory could thus be injected into geography, history, languages and the arts in suitable formats: science could make room for postmodern 
science (the new physical and life sciences, systems and complexity theory) and citizen science; moreover, all subjects could explore the multiple meanings and values that society assigns to nature, the environment and development.

Under such a system, subject knowledge could include more alternative technology (tools, ideas) that may allow students (citizens) to pursue their lives within an ecological frame, while citizenship education could investigate alternative forms of citizenship and democracy as well as how the varied discourses of environment and development melt one's identity. Of chief interest is the possibility that subject knowledge could be developed around a framework of the common issues that affect pupils' daily lives and could then be applied and assessed in community projects that seek greater sustainability (S.O.R.T.E.D., 2008)

\section{The multidimensional learning goals}

The revision of the English National Curriculum in 2000 introduced "a new agenda" for citizenship and sustainable development in primary and secondary schools. The geographers Powell and Basini (2006) have been examining how primary schools have planned or are planning to introduce these themes into their curricula. They have considered ways in which the study of geography, on a national and international scale, can provide a context for teaching these topics. They have defined four key aspects as important for teaching geography:

- The impact of the concept of citizenship in primary education in the native country and the wider world.

- The rationale for learning about citizenship and sustainability as part of a primary education curriculum.

- The development of citizenship and sustainability education through primary geography.

- Making connections across the school subjects (curriculum).

Citizenship issues are:

- Real: actually affect people's lives;

- Topical: current today;

- Sometimes sensitive: can affect people at a personal level, especially when family or friends are involved;

- Often controversial: people disagree and hold strong opinions about them;

- Ultimately moral: relate to what people think is right or wrong, good orbed, important or unimportant in society. (The Citizenship Foundation, 2008)

We need a sustainable and literate citizenry that is locally, regionally and globally aware. That is why education for sustainable living must be an important element in the geographical curriculum and a part of the citizenship curriculum and vice versa; why education for sustainable living should include geographical and citizenship content. That promotes understanding of the world around us, from local to global; understanding of the need to make lifestyle decisions that will allow us to maintain and improve the quality of our lives today while not imperilling the quality 
of life for generations to come, and, ultimately, an appreciation of why equity and justice are necessary to a sustainable society.

As defined by The Citizenship Foundation (2008) and several education researchers (Quisumbing, 2002; Bauer at al., 2003; Powell \& Basini, 2006; Kolenc Kolnik \&Resnik Planinc, 2006; Kolenc Kolnik ,2009) cross-curricular education should involve a wide range of multidimensional learning goals:

1. Knowledge and understanding: e.g. of topics such as nature or human rules, the democratic process, human rights, diversity, the economy, sustainable development and the world as a global community; and of concepts such as democracy, justice, equality, freedom and authority; knowledge of locations and places, ability to place national and international events in a geographical frame; understanding of basic spatial relations; understanding of the influence of natural conditions on human activities and various methods in the formation of environments according to their cultural values, religion, technical, economic and political systems; understanding and searching for answers to the challenges and possibilities within the framework of sustainable living as global co-dependence, etc.;

2. Skills and attitudes: e.g. critical thinking, analysis of information, expressing opinions, taking part in discussion and debate, negotiating, conflict resolution and participating in community action; the use of verbal, quantitative and symbolic information, identification of questions and results, collection and structuring of information, analysis of data, interpreting and evaluation of information, generalising, forming of opinions and evaluations, solving problems, making decisions, working logically and in harmony with acknowledged values, etc.;

3. Values and dispositions: e.g. respect for justice, democracy and the rule of law, openness, tolerance, courage to defend a point of view, willingness to listen, team work, standing up for others; interest in the surroundings and the natural and social characteristics of the surface of the Earth; care for the quality and planning of the environment; care for the life of future generations; readiness for responsible use of knowledge and skills in personal, professional and public life, etc.

All three groups of goals are aimed not only in the direction of geography or citizenship, but also towards important cross curricular effects that can influence pupils' grasp of the concepts of sustainable living. "It is artificial to try to separate learning of skills from knowledge, knowledge from values and so on. In practice, they are generally learned simultaneously rather than in isolation." (The Citizenship Foundation, 2008, p 2)

The most effective form of learning in cross-curricular education can be described as follows:

- active: emphasises learning by doing ( for instance: fieldwork)

- interactive: uses discussion and debate; to raise questions, to solve problems

- relevant: focuses on real-life issues facing people, society, nature;

- critical: encourages young people to think for themselves;

- collaborative: employs group work and co-operative learning, cross-curricular learning; 
- participative: gives young people a say in their own learning, in their own school or in their own local community. (Dyrfjord, Fumat, Pergar Kuscer, 2004)

Picture 3: Common goals: geography, citizenship and sustainable education

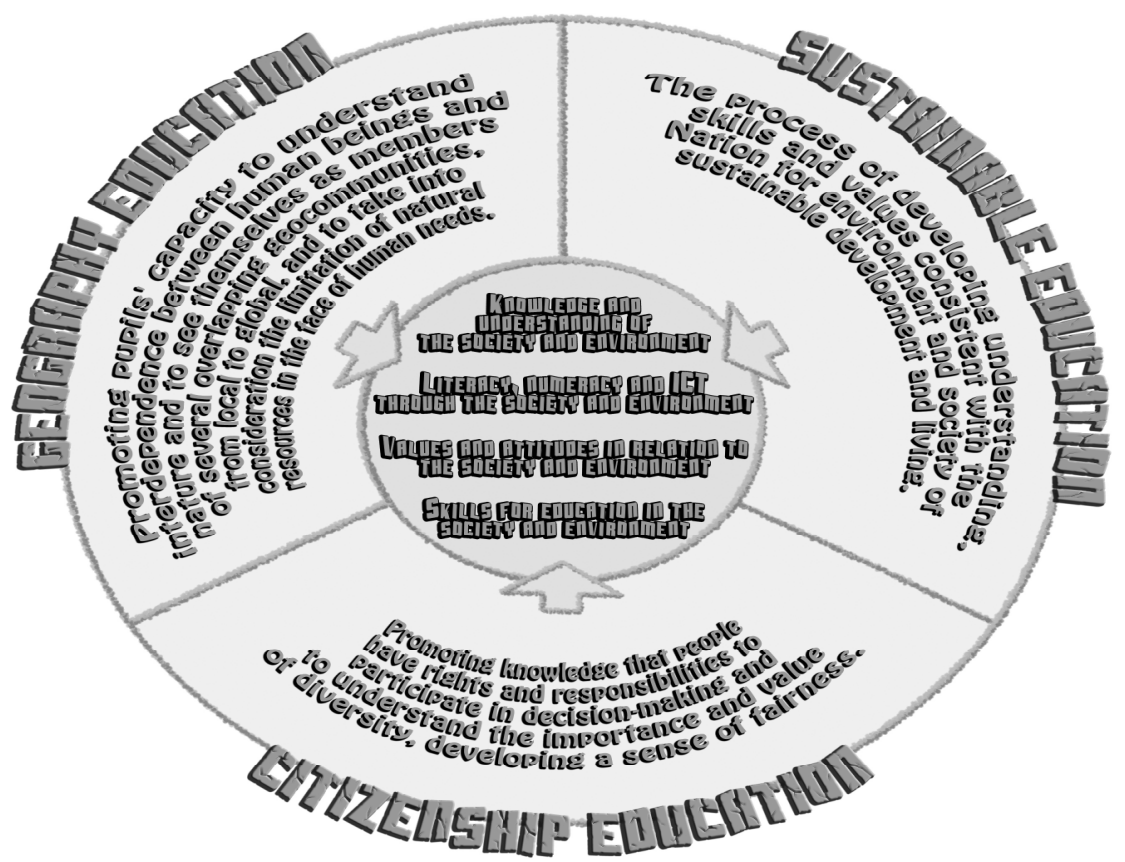

Source: Kolenc Kolnik, 2009

This type of learning demands a special climate in which to thrive - an environment that is non-threatening, in which young people can express their opinions without hindrance or embarrassment and take the initiative without fear of risk or failure. Such a learning climate needs time and patience so that it may gradually emerge. (Kolenc Kolnik, 2009)

\section{Conclusion}

Geography in school helps young people to know and understand the environment in which they live; it teaches them orientation and develops a responsible, binding and sympathetic relationship towards the natural and social environment as well as an appreciation of this environment. Moreover, it teaches them tolerance, and the importance of working towards a democratic society for everybody and the realization of personal freedom.

After comparing and analyzing the teaching goals and content of geography, civic education and sustainable development, we can claim that insufficient content 
from other scientific fields is included, in order to provide quality planning and implementation of lessons. At this point we need to stress the central importance of the interdisciplinary connection between all the fields of education, which is currently underestimated, even though many geographers flatter themselves that they have greater awareness because of the dual aspect (natural and social) of geography.

School geography, as well as all other fields of education, must give more fundamental systematic consideration not just to interdisciplinary, but also to the inclusion of formal, prescribed frameworks in the educational activity of public schools and the planning of curricula relating to the values and dimensions of sustainable development. Awareness of the challenges and traps of social development does not by itself change an individual's behavior and relation towards them.

The new directions in geography education are predicated not only on the need for knowledge, but also on critically stimulating its development. They view knowledge as a positional good that contributes to the personal social activity of the individual and enables the realization of his privileges, rights and social responsibility.

In order to implement these innovations in geographical education and education for sustainable development, stimuli for anticipatory learning and democratic participatory learning-based on interdisciplinary connections and a holistic approach-must be consolidated in a conjunction of necessary educational content for the purpose of creating an active citizenship. Contemporary forms of education and upbringing in favor of human rights and sustainable development simultaneously realize all of the most important goals of civic education. In particular, they highlight the role of various contemporary scientific disciplines, like geography, as potential co-founders of an educational policy with the aim of creating an active citizenship. Such forms of education will include the criteria of sustainable development, together with all the components of critical and creative thinking, as well as of directed and task-based learning, group work, teamwork, and self-realization through challenging instruction.

\section{Reference}

Bauer,T., Clarke, M., Dailidiene, E. (2003) Active Learning and Citizenship Education in Europe. The CiCe Thematic network project, London.

Bell, D. (2005). The value and importance of geography. Teaching geography. Vol.30. No.1, p. 12-13. Sheffield.

The Citizenship Foundation (2008). What is citizenship, and why teach it? http://www. citizenshipfoundation.org.uk/main/page.php?286, (accessed 10.10.1008)

Danciu, M., Clarke, M., Elm, A. (2005). Citizenship Education in First Cycle Undergraduate Teacher Education Courses. CiCe Guidelines on the Design of Higher Education Courses 1. London.

Dyrfjord, K., Fumat, Y., Pergar Kuscer, M., Andersen, R. (2004). Citizenship Education and Identity in courses for those who will work with Pre-school children, CiCe Professional Guidelines 1. London. 
Huckle, J. (2005). Education for Sustainable Development: a briefing paper for the Teacher Training Agency. http://www.ttrb.ac.uk/viewArticle.aspx?contentId=11693. (accessed 17.10.2008)

Interboard Education for Sustainable Development Group (2005). Education for Sustainable Development, Good Practice Guide for Primary, Secondary and special Schools, Curriculum Advisory \& Support Service, Northern Ireland..

Kolenc Kolnik, K., Resnik Planinc, T. (2006). Izobraževalno poslanstvo geografije. Šolsko polje. Vol. 17, No. 5/6, p. 71-82. Ljubljana.

Kolenc Kolnik, K., (2009). Geography and citizenship education for sustainable living: case study: Slovenia. Bielsko-Biała.

Powell, A., Basini, U. (2006). Developing global citizenship through geographical education: examples from Kerala, India. Changing Horizons in Geography Education, K. Donert and P.Charzyński (eds.). Torun. http://www.herodot.net/conferences/torun2005/Changing \%20Horizons \%20book.pdf\#page $=269($ accessed 17.10.2008)

Quisumbing, L., (2002). Citizenship Education for Better World Societies - A Holistic Approach. Paper presented at UNESCO-APEID International Conference. Bangkok.

Sibiu Declaration on Interdisciplinarity-draft version (2007). HERODOT Thematic Network for Geography in higher education .Meeting in Sibiu, October 25-28, 2007. Romania.

S.O.R.T.E.D. (2008). Integrating sustainable development into the curriculum, http://www.eauc.org.uk/sorted/integrating_sustainable_development_into_the_curri. (accessed 26.9.2008)

\section{Sources}

1 http://www.geographyteachingtoday.org.uk/ks1-3-courses/course/primary-geographyand-citizenship/stimulus2/ ( accessed 17.10.2008)

Curriculums in 9-year primary school in Slovenia: http://www.mszs.si/slo/solstvo/ss/ programi/geog.htlm/ (accessed 9.3.2008)

Metodički obzori 7(2012)3

Prethodno priopćenje

UDK: 371.3.035:91]:504

Received: 16. 3. 2011.

\section{ZAJEDNO: GEOGRAFSKA EDUKACIJA I GRAĐANSKI ODGOJ ZA ODRŽIVI ŽIVOT}

Prof. dr. sc. Karmen Kolnik

Oddelek za geografijo, Filozofska fakulteta, Univerza v Mariboru, Slovenija

e-mail: karmen.kolnik@uni-mb.si

\section{Sažetak}

Razumijevanje i ostvarivanje načela uravnoteženog održivog razvoja ne bi smjeli biti samo teme radnih dokumenata. Oni moraju postati komponente znanja i obrazovnih vrijednosti ugrađenih $\mathrm{u}$ obrazovni proces. Nove smjernice $\mathrm{u}$ obrazovanju na području geografije nisu određene samo potrebom za znanjem, već i kritičnim stimuliranjem njegova razvoja. U njima se znanje smatra statusnim dobrom koje doprinosi osobnoj socijalnoj aktivnosti pojedinca i omogućuje 
ostvarivanje njegovih povlastica, prava i društvene odgovornosti. Da bi se ove nove smjernice primijenile u geografskoj nastavi u cilju obrazovanja i vaspitanja za održivi razvoj, poticaji za anticipativno učenje i demokratsko participativno učenje, na osnovi interdisciplinarnih veza i holističkog pristupa, moraju se konsolidirati u smislu potrebnih obrazovnih sadržaja u svrhu stvaranja aktivnog građanskog odnosa.

Članak predstavlja neka gledišta koja se moraju razmotriti pri obrazovanju i odgoju održivih i pismenih građana koji posjeduju lokalnu, regionalnu i globalnu osviještenost. Da bi se to postiglo, međupredmetno obrazovanje mora uključivati širok raspon višedimenzionalnih ciljeva učenja. Nekoliko vrlo važnih navodi se u članku.

Ključne riječi: geografija, održivi život, građanstvo, interdisciplinarno učenje 